\title{
Good Europeans?
}

\author{
Euro-themes in Swedish, Danish and British TV News \\ during a November Week
}

\author{
KRISTINA RIEGERT
}

\begin{abstract}
Television news narratives are sites where national and transnational identities are cultivated and mobilised. The question is not whether Swedish, Danish or British news stories about Europe are domesticated to fit national news bulletins, but how events are domesticated and how 'we' are made European by the programmes' producers. The analysis of all European stories between 15-21 November 1999 in three national public service news bulletins indicate that viewers are offered different images of Europe during this week, and that journalists play active roles in constructing 'themes' which link together different types of news stories into narratives about 'us' and 'them'. From these there emerged a Swedish 'moralising global villager', slightly superior but willing to adapt to changing international realities, an anxious and conscientious Danish 'we', trying to do its share despite its self-imposed limitations on EU cooperation, and an engaged humanitarian British 'we', who is global in scope but prefers to keep a distance from time consuming Euro-squabbles.
\end{abstract}

Keywords: Europe, EU, national identity, European identity, television news, comparative studies.

\section{Introduction}

The electronic media, television in particular, have played a central role in two processes that have been the focus of debate in recent years: globalisation and localisation. The paradox is that while television news is often used to exemplify the increasing globalisation of cultures, it has traditionally sustained and cultivated a sense of national unity and national identity. Comparative national studies of international news content also reflect this paradox. De Vreese (2001) found that television coverage of the introduction of the euro in different countries used similar 'generic' themes, but that there were also significant issue-specific national spins in the news programmes. Other studies point to essential similarities in the way international events are themed across national boundaries, due to the dominance of an Anglo-Saxon culture of journalism, i.e. similar objectivity ideals, bureaucratic norms and a heavy reliance on official sources (Van Dijk, 1988). While there is no doubt that journalists are heavily dependent on Anglo-American international news agencies for both text and images, these very sources can be used to create news items that 'domesticate' foreign events by putting them into national 
political or cultural themeworks (Chin-Chuan Lee, et. al. 2000; Riegert, 1998; Cohen, et. al. 1996).

The similarities and differences documented in comparative studies of television news are attributable to both societal factors and media factors, and above all, to the complex interaction between the two. What Ekecrantz calls 'media societies' refers to the way societies shape the media, and to the simultaneous shaping by the media of the societies in which they are situated. The media should thus not be reduced to sites or arenas where social, cultural or political interaction is made visible - this interaction actually takes place in and through the media (Ekecrantz, 2000). From this point of view, what is interesting is not so much the existence of domesticated or generic international news coverage, but the means with which issues and events are domesticated or remain generic, what this says about the reporting societies, the societies reported on, and about their interaction with and through the media.

One way to study media societies is through the notion that television news is an important site for the cultivation and mobilisation of collective identities, i.e. transnational, national, or ethnic ones. On a daily basis, television news provides narratives about what events and issues 'we' should care about, what threats 'we' are exposed to, what catastrophes 'we' are providing aid for, and which summit meetings are going to affect 'us'. This cannot be done without a notion of the audience. Journalistic constructions of the audience can be discerned through what Allen (1992) calls television's rhetorical mode, which through direct address simulates face-to-face encounters. This means that in television's attempt to create an all-encompassing 'we' - audiences are represented back to themselves through the news presenters, reporters, officials, and vox populi on the screen. ${ }^{1}$ Journalistic texts thus divulge the position news programmes attempt to occupy in the public space and the ways audiences are conceived. One could say that television news tries to provide audiences with possibilities for identification, i.e. with identity mechanisms.

As is often noted, foreign news coverage is a genre where national identity mechanisms have been most manifest, where a government's actions become synonymous with the nation, acting and reacting to events and issues on an international stage. However, in an increasingly globalised media world, it is no longer a given that identity mechanisms are national or local ones. ${ }^{2}$ Indeed, as Becker, Ekecrantz and Olsson point out,

Although each event can be seen as originating in a specific place, and is therefore in some sense local, over time it may be and usually is recontextualized to encompass a broader geographic space. Conversely, an event which initially is defined as taking place on a national or international plane may over time move into a local context through the processes of journalism. ${ }^{3}$

Thus, it is possible that international news may increasingly reflect complex and overlapping national and transnational notions of 'us', activated by a constellation of the aforementioned societal and media factors, on journalistic sense-making of the news flow and on perceptions of the proximity of different stories at a particular point in time.

This article examines the coverage of news stories about Europe in Swedish, Danish and British television news programmes during the week 15-21 November 1999. Sweden, Denmark and Britain are all members of the European Union, yet all three have remained outside of the common currency - the euro - and, all have to varying extents significant Euro-sceptical portions of the population. The aim will first be to determine the contours of Europe in the different news programmes during this news week; secondly, to analyse 
the kind of national or international 'we' positions that are constructed in these European stories and how these are positioned against varying 'others'? And finally to compare how Swedish, Danish and British news makes sense of Europe at this particular point in time.

\section{Domesticated Foreign News and Globalised Domestic News}

One of the undeniable consequences of globalisation has been the blurring of the boundaries between foreign and domestic policy, and consequently that of traditional categories such as foreign and domestic news stories. Unfortunately, such a trend would be hard to track longitudinally since media scholars have used varying definitions of foreign news. For example, Larson (1984) defined foreign news as any mention of a foreign country in US network news programmes. Not surprisingly, he found that $43 \%$ of US news coverage in 1980 fit his definition. As Hess points out, this did not take into account that much US foreign news is domesticated, 'Half of American networks' international stories are about US citizens or US foreign policy/.../Nearly half of foreign dateline stories mention the United States'. ${ }^{4}$ Wallis \& Baran (1990: 172-3) tried to compensate for this weakness by introducing a sliding scale to gauge how 'domestic' and 'foreign' US, British and Swedish television news items were.

Although journalists still separate 'foreign' from 'domestic' stories, developments in television news point towards the merging of the domestic and foreign news desks, and indeed desk journalists are often cross-trained to cover both (Holm, 2001). Moreover, news programmes have not always been consistent in the division of the two: events and issues in other countries may be reported as domestically relevant, i.e. as a question of what may affect national interests. Issues and events involving the European Union are especially difficult to differentiate in that they engage the member states' domestic actors in a regional context, and are covered in newsrooms by both the domestic and foreign desks. Robertson found 'that domestic politics themed much of the discussion in the Swedish media of European political and economic issues' and that there was an 'emerging European dimension' to Swedish EU news. ${ }^{5}$ According to Claes de Vreese:

The 'internationalisation - domestication dynamic' inherent in news production is particularly visible in studies of news coverage of European affairs. First, Europe is becoming increasingly visible on national news agendas (an indication of internationalisation). Second, pan-European issues (such as the euro) are, on the one hand, domesticated in order to conform to the important 'proximity' news value. On the other hand, a number of areas and issues that have traditionally been confined to the nation state are becoming 'European'. ${ }^{6}$

Quantifying the scale of 'domestication' appears problematic in this light. Such a categorisation would not take into account domestic issues sparked by an international event, such as the Danish debate on foreign and defence policy as a result of the first meeting of EU defence ministers on 15 November 1999. Indeed, such a categorisation may count as 'foreign' the initial stories about the meeting of EU Foreign and Defence Ministers, but discount the subsequent domestic debate about the Danish exemptions ('forbehold') in relation to the European Union. It is thus important that the flow of stories and their context not be broken up by a division into a 'foreign' and a 'domestic' part. As described below, the perspective taken by much framing research tackles such problems by analysing the way news stories are structured and presented, rather than simply identifying the topics covered. 


\section{Methodological Notes}

As noted above, the choice of countries has to do with the distance all three countries have towards closer cooperation with the European Union. How is Europe depicted in the public service news programmes of three Euro-sceptical countries during an average week? ${ }^{7}$ De Vreese (2001: 189) suggests that news about the European Union peaks around major events, largely disappearing during routine periods. The week analysed here 15-21 November 1999 was not chosen due to any major event, although a meeting of EU Defence Ministers took place this week, as well as an OSCE summit meeting in Istanbul. While a week's news cannot be said to be representative of media coverage in general in these three countries, it is a contribution to existing studies of 'crossnational differences and similarities in framing Europe in the news' (De Vreese, ibid.; Robertson, 2000b; Robertson, 2001) and can be compared to them.

The European stories covered this week will first be analysed in terms of quantity, priority and topic. This may be seen as a sort of media map: what kind of Europe people, issues, events - do we see in the different news programmes this week? Secondly, the analysis looks at what identity mechanisms journalists use (national or international) to talk about what is relevant to 'us', and who the 'other' is in news stories about Europe. The result is what I call Euro-themes, these are similar to Entmen's (1993) elaboration of framing in news production to the extent that they are organisational devices which:

\section{I.../define problems - determine what a causal agent is doing with what costs and benefits, usually measured in terms of common cultural values; diagnose causes - identify the forces creating the problem; make moral judgements - evaluate casual agents and their effects; and suggest remedies - offer and justify treatments for the problems and predict their likely effects. ${ }^{8}$}

However, as DeVreese (2001) points out, much framing analyses lack concise operationalisations, and the news frames in the literature are too broad to be useful for an in-depth analysis such as this one, attempting to pinpoint identity mechanisms. For example, Neuman, Just and Crigler (1992) identified five frames in their study of media content and peoples' understandings of news: conflict, moral values, economics, powerlessness and human impact. De Vreese (2001: 182) solves this problem by using generic frames (conflict and economic consequences) and issue-specific news frames (disagreement, gains/losses) in his analysis of three different national media.

To avoid this problem, I identify 'Euro-themes' constructed by the news programmes by posing questions to the material such as: What aspects of Europe are highlighted in this story? What is the problem? What is the preferred solution? What does this event have to do with us? Who are 'us' and who are 'them'? What moral judgements are made? The themes described become evident through the journalists' address and choice of words, the way questions are posed, what aspects of an issue are highlighted, the causal and other relational links made between events, as well as what explanations are offered.

At times the news programme constructs a Euro-theme through creating links between two or more stories, such as using the merger of two companies to highlight the state of the Swedish defence industry in relation to Europe. Another way a Euro-theme was constructed was through developing stories over a sequence of days, such as European Union involvement in the British disagreement with France over its continued ban of British Beef. Through the news flow, such as stories that run over a period of 
days, and through the connections made between specific stories, i.e. references to European phenomena in stories with de facto different topics, the news programmes constructed themes which tell us who 'we' are in relation to Europe. The analysis identifies how this was done and demonstrates how these themes implicitly or explicitly serve to position a national or international 'we' in relation to certain 'others'.

\section{The Contours of Europe}

Europe is defined here as the geographic region from the Atlantic Sea to the Ural mountains, which means that Turkey and the Ukraine are included as European stories. The study includes stories about European countries other than the reporting country, as well as bilateral/multilateral European stories. The sample consisted of the main public service news bulletins in Sweden, Denmark and Great Britain: SVT's Aktuellt, DR's TVavisen and the BBC's Nine O'Clock News. TV-avisen is 25 minutes long, whereas both the Nine O'Clock News and Aktuellt are 30 minutes in length. ${ }^{9}$

During the week 15-21 November 1999, the Scandinavian media devoted substantially more overall attention to Europe than the Nine O'Clock News. Altogether, there were 88 'reads', voice-overs, news items and commentary classified as European stories this week. ${ }^{10}$ Aktuellt and $T V$-avisen had 38 and 35 European stories respectively, whereas the BBC had 15. If we look at the number of minutes devoted to European stories out of the total number of minutes available to each news programme, European stories accounted for $37 \%$ of Aktuellt's programme time, $27 \%$ of TV-avisen's programme time, and $18 \%$ of Nine O'Clock News programme time. ${ }^{11}$

Generally speaking, the Nine O'Clock News chose to focus mainly on domestic or non-European stories during the week in question. For example, the breakthrough in the Northern Ireland peace process was in the headlines on 6 out of the 7 days in this sample. Other stories were the first election for London mayor, the Egyptair plane crash, China's entry into the World Trade Organisation, and the announcement of the Prime Minister's new child. The main foreign news story in the Nine O'Clock News was Russia's war in Chechnya and the humanitarian situation of the refugees. Thus, despite the meeting of EU Defence Ministers about a European Rapid Reaction Force and the European Commission's negotiations with France over the ban on British beef, a British viewer could be forgiven for thinking that not much of importance was happening in Europe this week.

In contrast, Europe and the EU loomed large in both the Scandinavian news programs, supporting the adage that the smaller the country, the more important the outside world. Aside from EU issues, many of which were themed as domestically relevant for Sweden and Denmark, the European stories encompassed a range of political, economic and cultural events. It is noticeable, for example, that both the Swedish and Danish media have a number of stories about events in Britain and France - and these are not merely the standard political issues, but also 'soft' news stories. TV-avisen's Paris correspondent also contributed several news items: from the flooding in southern France, to the year's first Beaujolais wine, to the plans of French farmers to protest globalisation in Seattle. Aktuellt has a five-minute long critical exposé on the British practice of incarcerating underaged criminals using the news handle of the tenth anniversary of the UN Convention on the Rights of the Child. ${ }^{12}$

For all three news programmes, 'Europe' was basically Western Europe, with the exception of Russia. The major continuing story of the week was Russia's war in 
Chechnya and how this related to the Organization for Security and Cooperation in Europe's (OSCE) summit meeting in Istanbul. All three news programmes carried the following stories during the week under study:

1) The summit meeting of the Organisation for Security and Cooperation (OSCE) in Istanbul.

2) The Greek riots during the visit of US President Clinton to Athens.

3) The Russian bombing of Chechnya: the advance of Russian troops to Grozny and the situation of the Chechen refugees in neighbouring Ingushetia.

4) The second major earthquake in Turkey within several months.

5) A break-through in the Northern Ireland peace process.

6) The crisis between Britain and France, whereby France continued to ban British beef, prompting negotiations and legal actions by the European Commission.

The choice of stories evinces some shared agreement on newsworthiness among journalists in the three newsrooms regarding major European stories. However, these six stories were without exception covered with varying priority, intensity and/or news angles by each national medium. The reasons for this are obvious in the case of Northern Ireland and the ban on British beef, given that these were mostly and partly domestic news stories for the BBC. Less clear are the reasons for other differences: TV-avisen was the only programme to give the riots in Greece headline attention, Aktuellt gave the OSCE meeting headlines on two days, and the Nine O'Clock News prioritised the conduct of the war in Chechnya, with news items from the front-line or from neighbouring Ingushetia every day this week. Altogether, more than half of Aktuellt's European stories were EU-related, $43 \%$ of the Nine O'Clock News' European stories dealt with Russia's war in Chechnya, and TV-avisen prioritises different types of EU issues, but also events in France. Regarding the Nine O'Clock News and TV-avisen, the priority given to these stories may be related to the fact that the programmes have their own foreign correspondents on site.

\section{Europe in the Headlines}

The function of television news headlines is to attract the attention of the viewers, to highlight the importance of certain stories and to shape the coming bulletin. In the context of the issue-specific themes analysed in the next section, headlines can be considered one of the tools used to contain the topics and schema of stories, providing cues as to what and whom a story is about. Through including stories from different parts of the bulletin, and by making links between the topics to be covered, the headlines set the 'flow' of the programme. This latter function is evident during the week in question, not so much in the evidently 'European' stories presented in Figure 1, but in those stories which 'become European' through the links made to domestic issues within and between news items.

Aktuellt had more European stories in the headlines than the other programmes, and a larger number of domestic issues that are linked to the EU. The headline on 15 November, concerns Prime Minister Göran Persson's surprise statement that Sweden would join the euro 'sooner or later' - it was just a question of time. ${ }^{13}$ 
Figure 1. Swedish, Danish and British European Story Headlines ${ }^{14}$

\begin{tabular}{|c|c|c|}
\hline Aktuellt & TV-avisen & Nine O'Clock News \\
\hline $\begin{array}{l}15 / 11 \\
\text {-Göran Persson says yes to } \\
\text { the euro, but no word on } \\
\text { when Sweden will join. } \\
\text { 16/11 } \\
\text {-The missile system Bamse } \\
\text { gets a new chance when } \\
\text { Saab and Celsius merge. } \\
17 / 11 \\
\text {-The police investigate } \\
\text { illegal payments and } \\
\text { irregularities at the EU } \\
\text { Information Office in Stock- } \\
\text { holm. } \\
\text {-President Yeltsin at Istanbul } \\
\text { summit meeting today. } \\
\text { Russia rejects the West's } \\
\text { interference in the conflict in } \\
\text { Chechnya. } \\
\text { 18/11 } \\
\text {-Fraud scandal at the EU } \\
\text { Information Office grows. EU } \\
\text { Commission will investigate. } \\
\text {-Criticism prompted Yeltsin's } \\
\text { early departure from the } \\
\text { summit meeting in Istanbul. } \\
\text { 19/11 } \\
\text {-Saturday opening hours for } \\
\text { Systembolaget. } \\
\text {-Aktuellt interview with } \\
\text { Roman Polanski. }\end{array}$ & $\begin{array}{l}\text { 15/11 } \\
\text {-Historic day for EU defence } \\
\text { ministers. Military } \\
\text { cooperation is launched. } \\
16 / 11 \\
\text {-The Liberal Party wants to } \\
\text { resolve the government's EU } \\
\text { caution. All four Danish EU } \\
\text { exemptions should be } \\
\text { included in a referendum. } \\
\text {-French farmers go to the } \\
\text { US to fight hormone beef. } \\
\text { 19/11 } \\
\text { Thousands of demonstrators } \\
\text { show their hostility to the US } \\
\text { when President Clinton came } \\
\text { to Athens this afternoon. } \\
\text { 20/11 } \\
\text {-High Treason - the Danes } \\
\text { in STASl's archives. } \\
\text {-This Dane turned to } \\
\text { Strasbourg for human rights. }\end{array}$ & $\begin{array}{l}20 / 11 \\
\text {-Russian troops within } \\
\text { striking distance of Grozny. } \\
21 / 11 \\
\text {-Inside the Russian army. }\end{array}$ \\
\hline
\end{tabular}

The headline a day later - that the Swedish-produced Bamse missile system is saved through a merger between Saab and Celsius - refers to the story that partly Britishowned Saab will buy the Swedish arms company Celsius, making it Scandinavia's largest arms manufacturer. The relevance of this merger is 'do or die' for Sweden's arms industry and this prompts three items on Sweden's role in the European and global arms industry. On 17-18 November, the charges of fraud and illegal payments at the EU Information Office grow into a major scandal, challenged only by Yeltsin's rejection of Western criticism and early departure from the OSCE summit in Istanbul. The headline on 19 November refers to a controversial government decision to allow the Swedish state's liquor store (Systembolaget) to open on Saturdays. This, says the item, is prompted by pressure to ease alcohol restrictions due to increased smuggling and Swedish membership in the EU.

Danish TV-avisen's headlines on 15-16 November reflect the concern in Danish circles about the growing foreign and defence policy pillar of the European Union. The first meeting of European defence ministers had the aim of building a European rapid reaction force, but due to its EU exemptions, Denmark could participate in meetings, but was not involved in any decision-making. The next day, the Liberal Party MEP Lone 
Dybkjær, said that Denmark should make up its mind on the EU rather than standing on the sidelines. The second headline on 16 November refers to a special report by $T V$ avisen's Paris correspondent about a group of French farmers who 'have declared war against liberalised world trade' and are travelling to the WTO conference in Seattle to protest standardised farming and globalisation. There are no headlines on the OSCE summit or the war in Chechnya in $T V$-avisen, but the violent demonstrations in Athens following the summit are headlined. Finally, a bilateral issue makes the headlines - the Danish authorities requested access to STASI archives containing files of over fifty Danes suspected of cooperating with the former DDR.

As noted previously, the Nine O'Clock News covered few European stories this week, but highlighted the conduct of the Russian war in Chechnya and the humanitarian situation of the refugees. One reason for this is clear, the BBC got an exclusive: the headline on 21 November refers to an item where the BBC correspondent was said to be the only Western journalist allowed to ride with Russian troops. In a comparative perspective, the Nine O'Clock News' choice of headlined stories is interesting, due not to what was highlighted, but to what was not. It is puzzling, for example, that what $T V$-avisen calls a British initiative, the EU meeting for a common European rapid reaction force, was hardly covered at all in the Nine O'Clock News.

\section{Euro-themes in Swedish, Danish and British News}

Several overarching themes about Europe can be discerned in the stories prioritised by the news programmes during the week in question. As noted previously, these were generated by the links the programmes made between news items - they are either developing stories, where one day's story becomes the background for the next day's story, or they consist of connections made between different stories during a single broadcast. One might say that these stories build upon the narrative context of each other. The term 'narrative context' refers to the 'sense of 'a particular history that gives a news item (or part of that item) meaning'. ${ }^{15}$ Although Lewis (1996) used the narrative context to describe the way audiences understand news items, it could also be applied to the way journalists create meaning by constructing themes of reference which link one news story to another. The themes formed by these narrative contexts exhibit identity mechanisms positioning 'we' against certain 'others'. In a variety of ways, the Scandinavian news programmes enunciate a stronger 'we' than the Nine O'Clock News does.

\section{Sweden: The Moral Global Villager}

There are three themes that stand out in Aktuellt's depiction of Europe this week:

- The EU is a huge bureaucracy that is difficult to control.

- Sweden must adapt to Europe.

- Renewed East-West tensions. The West is partly to blame.

The first theme encompasses two interlinked stories about corruption and financial irregularities involving the European Union. They are linked together sequentially by Aktuellt on 16 and 17 November. The news presenter led into the first story thus: 'Today, the EU Commission has again been criticised for fraud and negligence with EU citizens' money'. This refers to a report released by the Swedish head of the European 
Court of Auditors, Jan O. Karlsson. Aktuellt's correspondent says: 'What is serious is that so little has improved despite earlier criticism. An estimated 5\% of the EU budget /.../ has been misused'. (16/11) Karlsson is said to be a critic, 'who, despite this, is a warm EU supporter and believes in a united Europe.' ${ }^{16}$ The 'read' following this item revealed another instance of corruption: the EU Information Office in Stockholm had been systematically paying salaries under the table. The headlines the following day confirmed that the fraud at the EU Information Office was a major story (see Figure 1). On 17 November, the two stories were again linked when Karlsson was asked to comment on the allegations against the EU Information Office. The rest of the week contained stories following up the investigations set up by the EU and the Swedish police. Both of these stories involved Swedes working for the EU, one of whom is fighting against what appears to be inevitable corruption, the other was depicted as accepting a side-effect of the EU bureaucracy - financial mismanagement or fraud. ${ }^{17}$ Despite this, the overall impression is not negative to the EU, since Swedish authorities were seen to be trying to do something about it. The stories thus demonstrate how Swedes, in this case 'we', can engage with the system and try to change things.

In the latter two Euro-themes, Aktuellt positioned the Swedish 'we' within European and global contexts. The second theme 'Sweden must adapt to Europe' is the most interesting, since it encompasses diverse stories: the defence industry, the likelihood of joining the euro, the plans to form a European rapid reaction force and the changes in the Swedish state alcohol monopoly. Aktuellt constructed these events in such a way as to demonstrate how Swedish politicians and industries are adapting or are going to have to adapt to economic changes in the surrounding world. In other words, the viewer is positioned to accept the necessity of adapting or coordinating with European and global actors. Those who are negative to these changes are out of step with the flow of events.

Take, for example, the discourse comprised by the three items emanating from the merger between Saab and Celsius on 16 November. The top story describes the economic background to the merger itself, saying that although the company may leave Swedish hands, it will facilitate the sale of Swedish-produced arms to other countries since it will become a multinational company. Analysts 'that Aktuellt has spoken to' say that the merger 'is the only way for the two companies to survive.' Indeed, 'a number of European countries hope that by coordinating their defence industries they can challenge US dominance in arms production' ${ }^{18}$ Here, the possibility that the merger might be considered a negative development is mitigated by Aktuellt's positioning of the Swedish defence industry within a larger European context.

The next story set the merger in the context of Sweden's foreign policy of non-alignment, i.e. Sweden's independent defence industry - its pride and joy during the Cold War Era - is said to be under pressure due to falling arms sales. Sweden's independence was 'an illusion' since 'we' had always been dependent on the US for equipment, but, the item said, European defence industries can no longer survive on their own. The item rounds off by saying 'From having been a non-aligned Sweden dependent on the US arms industry, we are becoming more and more dependent on Europe. ${ }^{19}$ This links into the following item which demonstrates the increasing defence cooperation among European countries and the problem of Europe's military dependence on the US. ${ }^{20}$ It is clear from the links made between these items that Swedish and European dependence on the US is considered problematic and unsatisfactory. The Swedish 'We' must adapt to Europe to meet the US challenge. 
This image of the US as a dominant competitor on the arms market overlaps to some extent with Aktuellt's third overarching theme, namely that of an increase in East-West tension, due in part to US policy. East-West tension is mainly conveyed through those items covering the OSCE summit in Istanbul and the confrontation between Russian President Boris Yeltsin and the 'West'. However, these are prefaced by two stories on 17 November about the complaints Russia planned to address at the summit. Russia protested the renewal of the US nuclear defence shield programme because it compromised existing arms agreements. In a studio commentary, security policy expert Gunnar Jervas, said that US insistence on a nuclear missile shield may create a chain reaction resulting in a general global 'rearmament'. The issue of whether a 'new Cold War' is signalled by the early departure of Boris Yeltsin from the OSCE meeting resurfaces the following day in another expert interview with Leif Kilsten. Kilsten says that the increased East-West tension is partly the fault of the 'West': NATO enlargement has made Russia feel isolated and, 'We have failed to include the Russian people in a warmer brotherhood with the rest of Europe.' ${ }^{21}$

The three issue-specific themes have in common a moralising Swedish 'we' set within a European and international context. The items in the first theme present the problems 'we' face when fighting the 'inevitable' corruption that stems from a large bureaucracy. The second and third themes differ in that the former places Sweden in a European context, where 'we' are attempting to assert ourselves against an economically powerful 'other' - the United States. The latter, on the other hand, positions 'the West' as bearing part of the responsibility for alienating a frightening and isolated Russian 'other'. Although the Swedish 'we' may be part of the negligent West in Kilsten's commentary, the other items in Aktuellt's coverage of East-West tension are characterised by accessing the positions and motives of both Russia and the US. Interestingly, the coverage of the OSCE summit and the war in Chechnya appear more as news handles to the analysis of East-West tension than the events that prompted them. The discourse in these news items is more reminiscent of Sweden's activist foreign policy of the 1970s and 80s which included a moral criticism of nuclear armament and the superpowers. ${ }^{22}$ Assessing the threat and assigning the blame, Aktuellt represents 'us' as concerned internationalist voices above the fray, and not one of 'others' who threaten to reignite the arms race.

\section{Denmark: The Conscientious European}

The need to coordinate European national defence industries is not dealt with in $T V$ avisen. As a member of NATO, Danish official policy has traditionally been hesitant of purely European defence initiatives, although this position has softened somewhat since the mid-1990s, despite its self-imposed exemption in that area. ${ }^{23}$ One type of military issue does surface on TV-avisen's agenda this week, but takes an altogether different turn. The three themes in $T V$-avisen which contribute to the impression that Denmark is represented as the 'conscientious European' are:

- Denmark is sidelined by EU defence cooperation.

- Denmark joins Western criticism of Russia's war in Chechnya.

- European institutions are positive for Danish interests.

In contrast to the other two news programmes, $T V$-avisen headlined the 'unprecedented' European Foreign and Defence Ministers meeting, the reactivation of the Western Eu- 
ropean Union (WEU) and events in their wake on 15 and 16 November. On 15 November, the news presenter opened the top story with a statement from the Foreign Minister who said that a national referendum on the Danish defence exemption was not on the cards. There were altogether five items dealing with this issue (four on $15^{\text {th }}$ and one the $\left.16^{\text {th }}\right)$. In the various interviews with Danish ministers, journalists from $T V$-avisen explored the issue of what their countrymen were doing at the meeting if they couldn't participate in EU decision-making, and whether the government had any plans for a referendum on the matter. Here, it is TV-avisen's journalists who are seen to be problematising the issue of Denmark's defence exemptions.

A day later, $T V$-avisen's line of questioning was reinforced and set into a domestic context when Liberal Party MEP Lone Dybkjær called for a referendum on all four of Denmark's EU exemptions. TV-avisen's correspondent Magnussen explained that the EU was cooperating in three areas where Denmark has exemptions: the common currency, on refugees and now on building a rapid reaction force. Dybkjær says that Denmark should decide once and for all whether 'we are in or out' instead of going 'around thinking that we are better than all the others, and the others notice this in fact/ $\cdots /$ at the same time that Denmark has had all the possible economic advantages of cooperation imaginable'. (16/11) The issue of an all-exemption referendum was now embraced by a Danish member of the European Parliament who had first-hand knowledge of EU cooperation. $T V$-avisen thus positions the viewer to question why Denmark is not being a 'good European' and participating in common efforts. This conclusion is shared by Anker Brink Lund (2000) who undertook a comprehensive study of most Danish mainstream media this very same week:

/.../there are many conflict-laden 'we's' at stake. Despite this, it appears that the coverage rests on the premise that a Danish acceptance of a transnational 'we' is an indisputable goal. Those who deviate are those who say no to a common Euro-identity in an upcoming EU-referendum. (2000: 24)

That Denmark actually does strive to be an active, dutiful member of both the EU and the 'West' is also demonstrated by TV-avisen's coverage of the OSCE summit in Istanbul. While Aktuellt used the OSCE meeting to highlight a general increase in East-West tension, with no reference to the Swedish government's position, $T V$-avisen's camera focused on the Danish Prime Minister as he took his seat among the other powerful statesmen. On both 18 and 19 November, TV-avisen singled out the position of the Danish Prime Minister, including soundbites of his criticism of Russia and his view that it is 'our responsibility' to keep up the pressure on the Russians to end their war in Chechnya. Thus, through the person of the Prime Minister, Denmark was depicted as an active part of the 'West's' attempts to protect humanitarian values regarding the situation in Chechnya.

The third issue-specific theme this week in $T V$-avisen consisted of news items which depicted the positive benefits of European institutions - for Danes. Two stories in this vein can be found in $T V$-avisen on 20 November. The headlined story dealt with a Danish citizen who, for the first time, sued and won a case against a foreign country (Luxembourg) at the European Court of Justice in Strasbourg. The lawyer on the case summed up the implications of the ruling: 'What we can say today is that the Strasbourg system works, even for Danes living in other countries'. The other story that day was about a Danish bird sanctuary that was being inspected by the EU. TV-avisen's news presenter leads into the item saying, 'The birds who visit Denmark are getting first-class accommodation according to the EU Commission, who praises us when it comes to 
protecting bird species'. Denmark is thus seen to have 'done its part' as a good European regarding environmental protection. Both items imply that the Denmark's participation in European institutions is to the benefit of Denmark and to Europe as well.

In comparison to the Swedish themes, the 'we's' that emerge from TV-avisen's coverage were more anxiety-ridden. The foreign minister and defence minister were brought in to explain exactly why 'we' cannot fully participate in EU defence cooperation. A more international 'we' is discerned in the way $T V$-avisen is at pains to project the Prime Minister's active role in 'Western' criticism of Russia and Danish participation in the OSCE security agreement. Later in the week, $T V$-avisen covered European stories which appear to demonstrate the benefits of being a 'good European'.

\section{Great Britain: Defender of Human Rights, but above Euro-Squabbles}

The differences in narrative style between the Scandinavian news programmes and the BBC could not be more pronounced. Whereas the news presenters and reporters in Aktuellt and $T V$-avisen constructed themes out of the flow of different news stories regarding Europe, explicitly linking national and transnational 'we's' with events in the surrounding world, the European stories in the Nine O'Clock News were interspersed with various domestic news items, giving a disjointed impression. The BBC's mode of address has been described by Robertson (2001: 21) as conforming to the 'conventions of realism', where the news presenter functions as an omnipresent, distanced narrator of events. ${ }^{24}$ Interestingly, the week in question provided evidence of this as well as a contrast, due to the engagement of the BBC's field correspondents in humanitarian catastrophes.

One theme in the Nine O'Clock News coverage of Europe encompassed diverse news items which all had to do with humanitarian tragedies: the Chechen refugees, the victims of the Turkish earthquake and the national catastrophe caused by rains in Southern France. In all these cases, BBC reporters described the suffering in poignant detail, choosing a family to symbolise the catastrophe and describing how they are coping with the loss of their loved ones and homes. The case of the Chechen refugees, which was the main focus of the BBC's coverage of the war in Chechnya in at least three of its seven items, is particularly interesting. On 17 November, the news presenter led into the item by saying that Russia gave permission to the head of UNHCR, Mrs. Sadako Ogata, to inspect the situation of the 200,000 refugees caught up in the fighting in Chechnya. Moscow correspondent Andrew Harding criticised Russian claims that this was a limited 'anti-terrorist' campaign:

The reality is much uglier. Russia is attacking Chechen towns and with savage indiscriminate force. The capital Grozny continues to burn, and the town is scarred by huge craters. There are still civilians living here, and every day brings more suffering. (17/11)

Harding's camera brings viewers into a hospital, where a two-year old Chechen ('in great pain') and his mother lie wounded, their male relatives dead after having been ambushed by Russian soldiers as they drove toward the border. Harding then drives 'straight to the border' to ask the Russians who was responsible. The Russian officer we see in picture, 'says he knows nothing about the incident', but Harding insists that this is clear 'evidence' that civilians are bearing the brunt of the fighting. He rounds off the item by saying, 'Russia's aims in Chechnya may be justifiable, its methods are anything but'. In this item, as in the others dealing with the Chechen refugees, the correspond- 
ent was engaged in the human tragedy. In the context of this week's coverage of the Western criticism of Russia at the OSCE summit, Harding took on the role of the eyes and ears of Western observers, upholders of humanitarian values. The viewer is encouraged to feel compassion for the Chechen refugees and outrage at the irresponsibility of the Russian 'others' who inflict pain on innocents. The 'we' that emerged is aligned with the 'Western' criticism of the Russian 'other'. Regarding both the Chechen coverage and that of the other natural catastrophes, the 'we' is that of concerned empathy for the unfortunate, not dispassionate detachment.

In contrast, there was little engagement on the part of the BBC in the EU Commission's attempt to mediate in the conflict between Britain and France regarding the latter's ban on British beef (due to fears of BSE, so-called Mad Cow disease). The crisis had been in the British headlines in the weeks before this one, and this was a period of EU-sponsored negotiations between the two governments. The EU Commission was to start legal proceedings to force the French to allow the sale of British beef, yet the two governments were at pains to emphasise that a 'diplomatic solution' was needed. At first, Europe correspondent Justin Webb simply reiterated the positions of the French and British, but as new actors appeared on the 18-19 November, the stakes become clearer. In particular, the protesting British farmers and British Conservative MEPs were angry. The former were described as 'fed up with Euro-compromise and looking for the French to be brought to heel', the latter were not satisfied with the EU Commission's compromise suggestion. Webb describes the British Conservative MEP's grievance that labelling British beef will become a stigma and undermine the sale of British beef. Although the British government and the farmers are said to be satisfied with the compromise, Webb identifies with the Conservatives when he rounds off his story:

And it is a fact that under the terms of that deal, British beef would be the only beef in France or Germany that had to be labelled with the country of origin. It is exactly what the French and Germans have been demanding'. (19/11)

In this theme, the EU is represented as one that facilitates compromise, but at the cost of 'our' interests - indeed the compromise is said to be identical to what the French/ Germans were 'demanding'. 'They' are thus not only the French (and the Germans) in this item, but the EU Commission which brokers a deal that is questionable to some British interests. In this way, this theme appears to confirm the inability of the EU to be effective in defence of 'our' (i.e. British) interests. As in the previous cases, the 'we's' in these themes are both international and national. The former is a Western 'we' which stands for humanitarian values against the Russian 'other', whereas the latter depicts the EU, the French and Germans as 'others' in opposition to British interests. Two alternative interpretations can be made of the BBC's humanitarian engagement with the sufferers of misfortune: a) either it has to do with a continued attachment to the context of the Cold War and the Russian enemy, or b) it is an attempt to engage viewers in the sufferers of misfortune. More research is needed to see whether the BBC continues to display themes of humanitarian engagement in the sufferers of misfortune.

\section{Conclusion}

This study has investigated identity mechanisms through tracing European stories reported in the main bulletins of Swedish, Danish and British public service news programmes during an average week. After noting how globalisation is affecting traditional 
divisions between foreign and domestic television news, and how this is especially prevalent in EU news, the analysis turned to what kind of Europe appeared in the different countries' news programmes. Judging by the attention given to European stories this week, it is clear that while Western Europe played a major role in the Scandinavian news programmes, their British counterpart preferred domestic or global stories. Although there was some convergence in the three newsrooms regarding major stories such as Russia's war in Chechnya and the OSCE summit in Istanbul - it was the differences, particularly in which stories were given headlines, that was most noticeable. Although both Aktuellt and TV-avisen prioritised EU-related stories, the events and their implications differed according to the domestic implications of the issue.

The analysis of the news stories themselves focussed on ways the news programmes attempted to theme and so to make sense of the European stories. These euro-themes could be discerned both in single stories and by the way different stories were linked together within a broadcast. All the news programmes evinced a combination of international and national 'we' constructions, although these differed from each other. The use of identity mechanisms in Euro-themes is quite explicit in Aktuellt and TV-avisen. Sweden came across in Aktuellt as the 'moral global villager': analysing the reasons for renewed East-West tensions and attributing the blame, but doing all in 'our' power to adapt to European financial, defence and alcohol policies, despite the corruption endemic to European institutions. Aktuellt depicted Sweden as internationalist and as 'good Europeans', even if 'they' have not got it 'right' yet. The US could be a powerful and intimidating 'other', but so could Russia.

Denmark emerged in TV-avisen as an anxious European, eager to do 'our' share in European cooperation, despite being sidelined by 'our' exemptions. TV-avisen seemed to be at pains to demonstrate how 'we' are an active part of the 'West' by foregrounding multilateral efforts and zooming in on its own Prime Minister in the criticism of Russia's war in Chechnya. The Danish 'We' also benefits from European institutions, and 'they' from 'us', perhaps, implying a need to justify European cooperation. EU issues were dwarfed by the resources, priority and pathos that the Nine O'Clock News gave to the human consequences of the war in Chechnya. In the narrative context of the issues this week, the coverage of civilians provided 'evidence' of the 'West's' criticism of Russia at the OSCE meeting. The Nine O'Clock News exhibits an international 'we' in its coverage of humanitarian tragedies, but in the coverage of the EU Commission's role in the negotiations over the beef ban, it is rather the national 'we' that had given into 'Them' (the French and Germans).

While this is a limited study, this week's news demonstrated that Europe meant different things in different national contexts and that 'we' constructions in relation to Europe are not necessarily national. Perhaps most important is the role of the journalists in the construction of these Euro-themes. The news presenters were particularly crucial in the Scandinavian news programmes: using lead-ins to theme the news items in certain ways, posing questions to studio guests, and in making links between different news items dealing with the similar issues. In the Nine O'Clock News, the themes were less enunciated and came across in the items by field correspondents rather than through the news presenters. Nonetheless, the national, European and Western constructions of 'We' appeared to be the driven just as much by the journalists as by the political actors involved in events. 


\section{Notes}

1. See also Allen 's earlier edition (1987), as cited in Edin (2000: 45).

2. Robertson and Hellman (1997) found evidence of emerging regional European and national identities in TV news.

3. Becker, Ekecrantz and Olsson (2000: 13).

4. Hess (1996: 8).

5. Robertson (2000a: 52).

6. de Vreese (2001: 189).

7. The material for the week of 15-21 November 1999 was gathered as part of a larger cross-national synchronic study comparing media texts and contexts in a large number of countries (See, Media Societies Around the Baltic Sea, 2001).

8. Entman (1993: 52). Italics original. Theme analysis has been applied to both news content as well as audience reception. Here we are concerned with the former. See also de Vreese (2001)

9. All programmes have 15 minute bulletins on Saturdays, whereas Sunday bulletins differ in each media (TV-avisen is 15 minutes, Nine O'Clock News is 20 minutes, and Aktuellt is 15 minutes).

10. 'Reads' are several sentences read by the anchor to a still photograph, a voiceover is often between 2030 seconds in length and is read by the anchor to video footage and a news item is a report by a correspondent outside of the studio. Commentary items are most often studio-based.

11. Percentages are rounded up at .5. Aktuellt devoted 66 minutes, 40 seconds to European stories, whereas TV-avisen devoted 42 minutes and 1 second, and the Nine O'Clock News devoted 32 minutes and 27 seconds to European stories. The percentages are based on a total of 180 minutes for the entire week for Aktuellt and the Nine O'Clock News (weekend broadcasts, 15 minutes long) and 155 minutes for TV-avisen ( 25 minutes each night and 15 minutes on Sundays).

12. The culturally competent will note that corporal punishment is one area where Swedish and British culture diverge sharply.

13. Aktuellt devotes five items that day to the euro. These include the Prime Minister's statement to the Financial Times after which there are two studio guests from each 'camp' discussing the Prime Minister's statement, an item on the reaction by a Euro study circle of grass roots' Social Democrats, an item on anti-Euro Social Democrats and finally Aktuellt's political commentary.

14. All translations from Swedish and Danish in this chapter are done by the author. The Danish party det Radikale Venstre" is here translated as the Liberal Party.

15. Corner \& Harvey's introduction to an essay by Justin Lewis (1996: 41).

16. Helena Stålnert, news presenter, Aktuellt, 16 November 1999.

17. The scandal deepened not least because the Swedish director of the EU Information Office was said to have known about the allegations and done nothing to stop it.

18. Mattias Long, reporter, Aktuellt, 16 November 1999.

19. Anita Krantz, reporter, Aktuellt, 16 November 1999.

20. The same issue is followed up on 17/11 in a news item about the EU plans to build an independent 'military capacity' so as 'not to be as dependent on the US on defence issues as during the military efforts in Bosnia and Kosovo'.

21. Leif Kilsten, studio interview, Aktuellt, 18 November 1999

22. See, for example, Bjereld (1992).

23. Larsen (2000)

24. In another study, Robertson (2000b) also found the BBC World also tends to address its audience from the position of the omiscent reporter telling viewers for their "information" that something has happened.

\section{References}

Allen, Robert (1992) 'Audience-Oriented Criticism and Television', in Allen, R. (ed.) Channels of Discourse, Reassembled. Television and Contemporary Criticism. London: Routledge.

Bjereld, Ulf (1992) Kritiker eller medlare. Stockholm: Carlsson.

Becker, K., Ekecranz, J., Olsson, T. (2000) 'Introduction: Picturing Politics in $20^{\text {th }}$ century Sweden', in Becker, K. Ekecranz, J. and Olsson, T. (eds.) Picturing Politics: Visual and Textual Formations of Modernity in the Swedish Press. JMK Skriftserie, Stockholms Universitet. Stockholm.

Chin-Chuan, L., Man Chan, J., Pan, X. and So, C.Y.K. (2000) 'National Prisms of a Global 'Media Event' in Curran, J. and Gurevitch, M. Mass Media and Society. $3^{\text {rd }}$. ed. London: Arnold.

Cohen, A., Levy, M., Roeh, I., Gurevitch, M. (eds). (1996) Global Newsrooms, Local Audiences. London: J. Libbey. 
de Vreese, C. (2001) 'Themes in Television News. British, Danish, and Dutch Television News Coverage of the Introduction of the Euro', in Hjarvard, Stig (ed.) News in a Globalized Society. Göteborg: Nordicom.

Donsbach, W. (1995) 'Lapsdogs, Watchdogs and Junkyard Dogs', Media Studies Journal, Fall: 17-30.

Edin, Anna (2000) Den föreställda publiken: programpolitik, publikbilder och tilltalsformer $i$ svensk publicservice-television. Stehag: Symposion.

Ekecrantz, Jan (2000) Modernity, Media and the Global System: A Timeless World? Södertörns Högskola, Research Reports, 2/2000. Växsjö.

Entman, R. (1993) 'Framing: Toward Clarification of a Fractured Paradigm', Journal of Communication. (43) 2: 51-58.

Hess, Stephen (1996) International News \& Foreign Correspondents. Washington, D.C.: Brookings Institution Press.

Holm, Hans-Henrik (2001) 'The Effect of Globalisation on Media Structures and Norms. Globalization and the Choice of Foreign News', in Hjarvard, Stig (ed.) News in a Globalized Society. Göteborg: Nordicom.

Holst, Maja \& Lolk, Mette (2000) 'Formidling af Risiko', in Brink Lund, A. (ed.) Først med det Sidste - en nyhedsuge i Danmark. Århus: Jour

Höijer, Birgitta, Nohrstedt, Stig-Arne, Ottosen, Rune (2001) 'The Kosovo War in the Media - Analysis of a Global Discursive Order'. Paper presented at the IAMCR conference "Peace and Communication", Budapest, September 7-8, 2001.

Jensen, Klaus Bruhn (1998) News of the World. London: Routledge.

Jensen, Klaus Bruhn (1994) 'The 'New Television Viewer Revisited', Cultural Studies No. 2, Vol. 8. May.

Jensen, Klaus Bruhn (1986) Making Sense of the News: Towards a Theory and Empirical Model of Reception for the Study of Mass Communication. Aarhus: Aarhus University Press.

Larsen, Henrik (2000) Denmark and the European Defence Dimension in the Post-Cold War Period: Optout or Participation? Report 2000/3. Danish Institute of International Affairs (DUPI).

Larson, James (1984) Television's Window on the World: International Affairs Coverage on US Networks. NJ: Ablex.

Lewis, Justin (1996) 'Decoding Television News', in Corner, J. \& Harvey, S. (eds.) Television Times: A Reader. London: Arnold.

Lund, Anker Brink (2003) 'The Mass Mediated "We" in Danish Journalism', in eds. Ekecrantz, Olsson, Riegert, \& Åker (eds.) Media Societies 2000. Huddinge: Södertörns Högskola. Project report.

Lund, Anker Brink (2000) 'Kampen om det danske vi', in Lund, A.B. (ed.) Forst med det Sidste - en nyhedsuge i Danmark. Århus: Jour.

Media Societies Around the Baltic Sea (2001) Södertörns Högskola. Project description

Neuman, W.R. Just, M. \& Crigler, A. (1992) Common Knowledge: News and the Construction of Political Meaning. Chicago: University of Chicago Press.

Riegert, Kristina (1998) 'Nationalising” Foreign Conflict: Foreign Policy Orientation as a Factor in Television News Reporting. Edsbruk: Akademitryck.

Robertson, Alexa (2001) 'Us, Them in Television News Narratives', Paper presented at the Arts and Politics Conference on Narrative, Identity and Order at the University of Tampere, 13-15 September 2001.

Robertson, Alexa (2000a) Depictions of the European Union in 19 Swedish Media. Stockholm: Mediagruppen. Report for Swedish Ministry for Foreign Affairs.

Robertson, A. (2000b) Europa erzählt: Erzählananlyse und Fernsehnachrichten über Europa' [Telling Europe: Narrative analysis television news stories about Europe] in J. W. Deth and T. König, eds. Europäische Politikwissenschaft: Ein Blick in die Werkstatt.Frankfurt/New York: Campus Verlag.

Robertson, A. \& Hellman, M. 'Identify in the News of Europe: Looking for Traces of Identification Processes in British, French, German and Swedish Television News. Paper written for the Identity in the New Europe Workshop, ECPR Joint Sessions in Bern, 27 February-4 March 1997.'

Shudson, Michael (2000) 'The Sociology of News Production Revisited (Again)' in Curran, J. and Gurevitch, M. Mass Media and Society. $3^{\text {rd }}$. ed. London: Arnold.

Van Dijk, Teun (1988) News Analysis. Case Studies of International and National News in the Press. London: Lawrence Erlbaum Associates.

Wallis, Roger and Baran, Stanley (1990) The Known World of Broadcast News: International News and The Electronic Media. London: Routledge.

KRISTINA RIEGERT, Ph.D., Associate Professor, Department of Culture and Communication, Södertörn University College, P.O. Box 4101, SE-141 89 Huddinge, kristina.riegert@sh.se 